\title{
Relationship between Nursing Staff's Decisional Involvement and Their Decision-Making Abilities in Cairo University Hospital
}

\author{
ALYAA A. AHMED, M.Sc.; EGLAL A. ABD EL-WAHAB, D.N.Sc. and SAHAR H. ALY, D.N.Sc. \\ The Department of Nursing Administration, Faculty of Nursing, Cairo University
}

\begin{abstract}
Background: Decisional involvement recommends the decentralization of decision-making and the proximity of staff members who provide healthcare, in which workers have their participation ensured and are entitled to take part in discussions concerning the decision-making process. Decisional involvement is important in healthcare and initially adopted in for the nursing discipline to achieve excellence in patient care.
\end{abstract}

Aim of Study: To investigate the relationship between nursing staff's decisional involvement and their decisionmaking abilities in New Kasr El-Aini Teaching Hospital.

Material and Methods: A descriptive correlational research design was utilized to carry out the study. One hundred and fifteen baccalaureate nurses including one nursing director, three associate directors, thirty-nine supervisors, thirty-six head nurses, twenty-two charge nurses and fourteen staff nurses. Two tools were used to collect data. First tool divide to two parts demographic data and nurse's decision making involvement questionnaire, second tool was nursing staff's decision making abilities questionnaire.

Results: Study findings revealed that there was a statistical significant correlation between study demographic characteristics and decision making abilities. While, there is no statistical significant correlation between study demographic characteristics and decision making involvement. Also, there was no statistical significant correlation between study sample's decision making abilities and their decision making involvement.

Conclusion: The study concluded that decisional involvement is performed according to the management positions regardless the staff abilities to make a decision.

Recommendations: It is recommended that the organization should provide training courses to improve decision making abilities of nursing staff. Also, nursing director should increase their involvement in decision making process and put an evaluative measure to be used as a standard in choosing managerial and administrative position regarding their abilities and skills regardless their ages.

Key Words: Decision making - Decisional involvement Nursing - Abilities.

Correspondence to: Dr. Alyaa A. Ahmed, The Department of Nursing Administration, Faculty of Nursing, Cairo University

\section{Introduction}

HEALTH care environment is characterized by its dynamic and uncertainty situations which require nurses to be competent decision makers in order to respond to clients' needs which rapidly change. Also, rapid advancements in medical technology and financial resources create uncertainty in health care organizations and require redesign of its structure and its care process that increased nurses' responsibilities in caring for patients. Therefore, nurses require greater autonomy and decisional involvement that results in better outcomes [1].

Effken, Verran, Logue \& Hsu [2] added that nurses who work in nursing services management spend most of their time analyzing situations and making decisions. They have an obligation to create care delivery climates that promote critical thinking that leads to innovative solutions to problems within the system of care [3].

Over the past decade, the increasing complexity of clinical nursing has entailed more informed decision-making to ensure effective and safe nursing practice. Therefore, clinical decision making is considered as integral part to nursing practice which influences patient outcomes. A manager's decision must be timely, based on clinical reality, consonant with personnel and material resources and communicated to motivate the subordinates who will implement the decision in order to change the undesirable work situation [4].

Decisional involvement is known as a strategy used to transform organizations, improve productivity, empower staff nurses, enhance staff nurses autonomy, increase job satisfaction and reduce nursing turnover [5]. It is introduced in 1970's to enable nurses to exercise control and to make decisions about their practice, for promoting rela- 
tionships and responsibilities between nurses and organizational leaders, as well as develops equality and parity [6].

The success of nursing decisional involvement practices can be achieved through designing a supporting structure to fit the philosophy of the organization which has long been promoted as an effective strategy for improving work environments by providing nurses a mechanism to assume responsibility of nursing practice. Regardless the structure, decisional involvement implementation will establish the expectation for nurses participation and the acceptance of personal accountability. It is a key empowerment mechanism in nursing organizations $[6,7]$

In decision-making, nurses are required to optimize their professional knowledge and skills, clinical experiences, knowledge of self and patients, and insight [8]. They must constantly examine their decisions and action outcomes. By maintaining an open mind, nurses can innovatively develop choices from which to choose when making decisions. Therefore, decision making abilities are crucial in the decision-making process. It includes the following abilities as critical thinking, reflection, reasoning, communication skills, evidence-based approaches, recognition, Intuition, creativity, autonomy, self-awareness and experience [9].

\section{Material and Methods}

Setting: The study was conducted at a Teaching Hospital which is affiliated to the Cairo University from 17-6-2017 till 23-11-2017.

\section{Research questions:}

1- What is the type and frequency of the nursing staff's decisional involvement?

2- What are the decision-making abilities of nurses?

3- What is the relationship between nursing staff's decisional involvement in hospital and their decision-making abilities?

Sample: The study sample included all baccalaureate nurses who working at the selected hospital. They were one hundred and fifteen nurses including one nursing director, three associate directors, thirty-nine supervisors, thirty-six head nurses, twenty-two charge nurses and fourteen staff nurses.

Data for the present study were collected by using the following tools:

1- First tool: "Nurses' involvement in decision making questionnaire": It was developed by the investigator based on decisional involvement scale [10], and index of professional nursing governance [11]. It was answered by nurses to assess their perceived involvement in decisionmaking. It consisted of two parts:

A- First part:It includes the demographic data of the study participants. It included age, educational level, employment status, years of experience (in nursing, in the present position, and in the present organization), the type of Nursing Unit, and attended training courses related to management and the primary work area in the hospital.

B- Second part: It is the "nurse's decision making involvement questionnaire". It included 33 items related to decisional involvement which measure the perceived decisional involvement of baccalaureate nurses. It consisted of five sub scales as follows: Control (14 items), official authority (9 items), participation (5 items), conflict resolution (4 items), and access to information (1 item). The participants rated their responses against 5-point Likert scale as follows: Administration/management only $=1$; primarily administration/management with some staff nurse input=2; equally shared by administration/management and staff nurses $=3$; primarily staff nurses with some administration/management input $=4$; and staff nurses only $=5$, results can be considered by individual items, by subscale, or as an overall scale.

2- Second tool: "Nursing staff's decision making abilities questionnaire". It was developed by the investigator based on decision-making questionnaire [12] and Nurse manager skills inventory [13]. It consisted of 35 items that representing different decision making abilities such as creativity (3 items), reasoning ( 2 items), critical thinking (3 items), evidence-based ( 2 items), self-awareness (2 items), reflection (3 items), recognition (4 items), communication skills (4 items), intuition (3 items), autonomy (5 items) and experience (4 items). The participants rated their responses against a 3-points likert scale as follows: A) Score "never=1 to always=3".

Procedure: For ethical reasons an official permission was granted from the Research Ethical Committee as well as the hospital administrators. In June 2017; each participant was approached to give them an oral explanation and clarification of the aim of the study. Confidentiality was assured through coding the data. A written consent was obtained from the participants who agree to participate in the study. The researcher distributed the questionnaire to participants in the different shifts from 10am until 12:30pm and from $7 \mathrm{pm}$ until 
9:30pm, after clarification of the way of answering them, the time of completing the questionnaires ranged from 30 to 45 minutes. Data collection consumed 6 months (from June until November 2017).

Statistical analysis: The collected data was summarized and tabulated using SPSS program. Descriptive statistics was done using frequency, percentage distributions, mean and standard deviation.

\section{Results}

Table (1) shows that the mean age of study sample was $40.17 \pm 8.51$, while the mean of their years of experience in nursing was $17.20 \pm 8.29$, compared to $15.54 \pm 7.85$ years of experience in the organization. As regards to study sample years of experience in the current position, the mean was $9.32 \pm 6.16$. The highest percentage $(27.8 \%)$ of study sample age range $(30<40)$. The highest percentage $(24.3 \%)$ of study sample years of experience in nursing range $(10<15)$ years; $(47.8 \%)$ of them had years of experience in the organization $\geq 15$ years and $(33 \%)$ of them had experience in their current position range ( $\geq 5$ years). Moreover, the majority $(83.5 \%)$ of study sample had baccalaureate degree in nursing while the lowest percentage $(7.8 \%)$ had master degree in nursing.

Fig. (1) displays that the majority (83.5\%) of study sample had baccalaureate degree in nursing, while the lowest percentage $(7.8 \%)$ had master degree in nursing. Moreover, Fig. (2) shows the majority $(95.7 \%)$ of study sample was working full time. Additionally, Fig. (3) represents that about one third of study sample were working as head nurses and one third as supervisors.

Table (2) represents means and mean percentages of study sample decision making abilities. The study findings represented that ranking of highest mean percentages were given to reasoning, experience, recognition, critical thinking and selfawareness abilities $(91.61 \%, 89.13 \%, 87.75 \%$, $85.60 \%$ and $83.33 \%$ respectively). While, the lowest mean percentages were given to intuition and reflection abilities $(65.41 \%$ and $69.37 \%$ respectively).

Moreover, (Table 3) regarding to mean and mean percentage of study samples' decision making involvement, the results of the present study showed that the highest mean percentage $(49.61 \%)$ was given to controlling, while the lowest mean per- centage $(40 \%)$ was given to information access dimension.

Finally, Table (4) shows that there is no statistical significant correlation between study sample's decision making abilities and their decision making involvement ( $p=0.38)$.

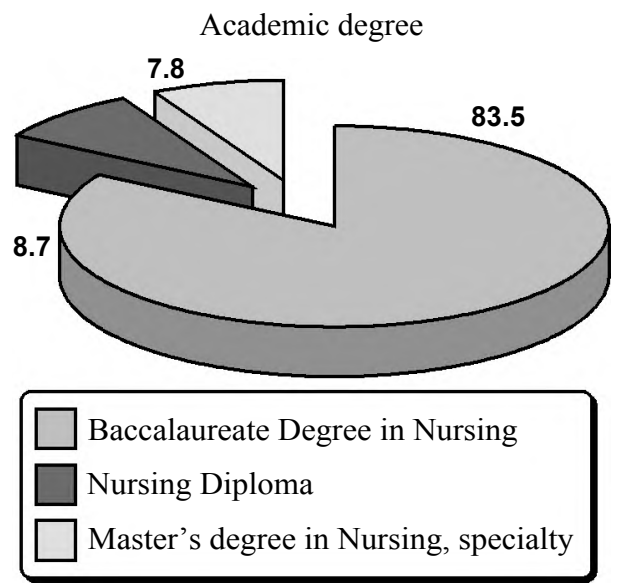

Fig. (1): Frequency distribution of study sample regarding to their academic degree.

\section{Employment status}

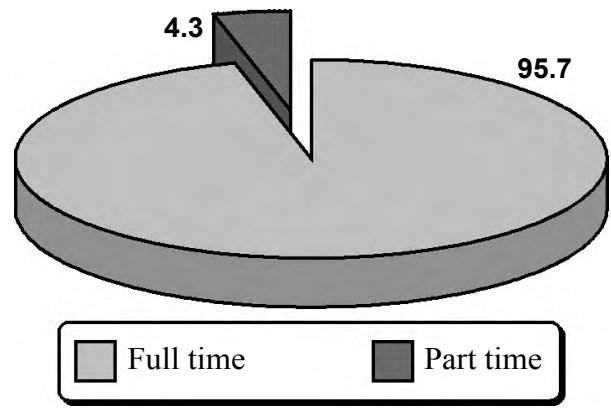

Fig. (2): Frequency distribution of study sample regarding to their employment status.

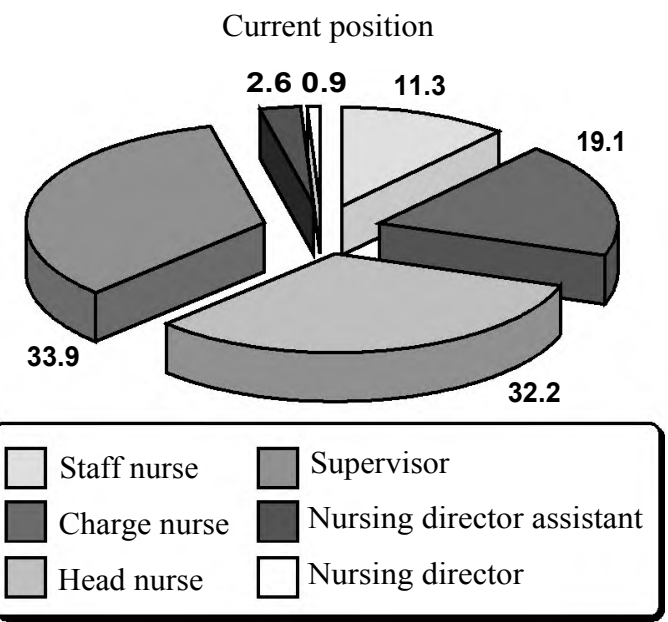

Fig. (3): Frequency distribution of study sample regarding to their current position. 
Table (1): Frequency distribution of the demographic characteristics of study sample $(n=115)$.

\begin{tabular}{|c|c|c|}
\hline Demographic characteristics & $\mathrm{N}$ & $\%$ \\
\hline \multicolumn{3}{|l|}{ Age: } \\
\hline$<30$ years & 17 & 14.8 \\
\hline $30<40$ years & 32 & 27.8 \\
\hline $40<50$ years & 48 & 41.7 \\
\hline$\geq 50$ years & 18 & 15.7 \\
\hline Mean \pm SD & \multicolumn{2}{|c|}{$40.17 \pm 8.51$} \\
\hline \multicolumn{3}{|l|}{ Years of experience in nursing: } \\
\hline$<5$ years & 11 & 9.6 \\
\hline $5<10$ years & 6 & 5.2 \\
\hline $10<15$ years & 28 & 24.3 \\
\hline$\geq 15$ years & 70 & 60.9 \\
\hline Mean \pm SD & \multicolumn{2}{|c|}{$17.20 \pm 8.29$} \\
\hline \multicolumn{3}{|c|}{ Years of experience in the organization: } \\
\hline$<5$ years & 14 & 12.2 \\
\hline $5<10$ years & 10 & 8.7 \\
\hline $10<15$ years & 36 & 31.3 \\
\hline$\geq 15$ years & 55 & 47.8 \\
\hline Mean \pm SD & \multicolumn{2}{|c|}{15.547 .85} \\
\hline \multicolumn{3}{|c|}{ Years of experience in current position: } \\
\hline$<5$ years & 38 & 33.0 \\
\hline $5<10$ years & 21 & 18.3 \\
\hline $10<15$ years & 34 & 29.6 \\
\hline$\geq 15$ years & 22 & 19.1 \\
\hline Mean \pm SD & \multicolumn{2}{|c|}{$9.32 \pm 6.16$} \\
\hline
\end{tabular}

Table (2): Mean and mean percentage of study sample's decision making abilities $(\mathrm{n}=115)$.

\begin{tabular}{llcc}
\hline $\begin{array}{l}\text { Decision making } \\
\text { abilities }\end{array}$ & Mean \pm SD & $\begin{array}{c}\text { Maximum } \\
\text { mean }\end{array}$ & $\begin{array}{c}\text { Mean } \\
\text { percentage }\end{array}$ \\
\hline Autonomy & $12.12 \pm 1.36$ & 15 & 80.8 \\
Intuition & $5.89 \pm 1.14$ & 9 & 65.41 \\
Communication skills & $8.69 \pm 0.86$ & 12 & 72.39 \\
Self-awareness & $5 \pm 0.79$ & 6 & 83.33 \\
Evidence-based & $4.44 \pm 0.98$ & 6 & 74.06 \\
Critical thinking & $7.70 \pm 1.43$ & 9 & 85.60 \\
Reasoning & $5.50 \pm 0.73$ & 6 & 91.61 \\
Creativity & $6.64 \pm 1.24$ & 9 & 73.81 \\
Experience & $5.35 \pm 0.75$ & 6 & 89.13 \\
Reflection & $6.24 \pm 1.02$ & 9 & 69.37 \\
Recognition & $10.53 \pm 1.43$ & 12 & 87.75 \\
\hline Total & $78.10 \pm 5.79$ & 99 & 78.88 \\
\hline
\end{tabular}

Table (3): Mean and mean percentages of study sample's perception of their decision making involvement and its types $(\mathrm{n}=115)$.

\begin{tabular}{llll}
\hline \multirow{2}{*}{$\begin{array}{l}\text { Decision making } \\
\text { involvement }\end{array}$} & Mean \pm SD & $\begin{array}{c}\text { Maximum } \\
\text { mean }\end{array}$ & $\begin{array}{c}\text { Mean } \\
\text { percentage }\end{array}$ \\
\cline { 2 - 4 } & $34.73 \pm 9.15$ & 70 & 49.6 \\
Control & $19.25 \pm 5.87$ & 45 & 42.8 \\
Authority & $12.02 \pm 3.76$ & 25 & 48.1 \\
Participation & $2 \pm 0.98$ & 5 & 40 \\
Access to information & $9.14 \pm 3.76$ & 20 & 45.7 \\
Conflict resolution & $77.20 \pm 17.92$ & 165 & 46.8 \\
\hline Total & &
\end{tabular}

Table (4): Correlation between total of mean scores of the study sample's decision making abilities and their decision making involvement $(\mathrm{n}=115)$.

\begin{tabular}{lcc}
\hline \multirow{2}{*}{ Variables } & \multicolumn{2}{c}{ Decision-making abilities } \\
\cline { 2 - 3 } & $r$ & $p$ \\
\hline Decision-making involvement & 0.08 & 0.38 \\
\hline$*: p$-value is statistically significant at the level of $\leq 0.05$.
\end{tabular}

\section{Discussion}

The findings of the present study showed that, the mean age of study sample was $40.17 \pm 8.51$, the highest percentage $(27.8 \%)$ of study sample age ranges from 30 to less than 40 years. Congruently, Bina et al., [14] and Scherb, Specht \& Loes [15] stated that mean age between study participants was $(43.39 \pm 10.58 \& 40.65 \pm 11.24$, respectively). Incongruently, Ahmed \& Safadi [16] represented that the mean age of their study sample was $26.7 \pm$ 6.07 , while the majority of study sample aged 2025.

Moreover, the mean of their years of experience in nursing was $17.20 \pm 8.29$, compared to $15.54 \pm$ 7.85 years of experience in the organization. As regards to study sample years of experience in the current position, the mean was $9.32 \pm 6.16$. The highest percentage $(24.3 \%)$ of study sample years of experience in nursing range from 10 to less than 15 years; (47.8\%) of them had years of experience in the organization more than 15 years and (33\%) of them had experience in their current position range ( $<5$ years). In contrast with the current study results regarding experience years in nursing; Ahmed \& Safadi [16] majority of the sample had $(<5)$ years of experience, on the other hand, the minority had $(>10)$ years of experience with mean 4.6 \pm 4.7 . Furthermore, Bina et al., [15] and Scherb, Specht \& Loes [16] mentioned that mean of years in nursing (15.77 \pm 11.13 and $17.41 \pm 10.57$, respectively) with range (1-42 and 0.5-52 years, respectively). Scherb, Specht \& Loes [16] found those years in current position $9.51 \pm 8.78$ with range 140. While, experience years at the organization had mean $14.23 \pm 9.68$ and years ranging from 0.5 to 46 years.

The present study findings concealed that the majority $(83.5 \%)$ of study sample had baccalaureate degree in nursing while the lowest percentage $(7.8 \%)$ had master degree in nursing. It revealed that the baccalaureate nurses feel satisfied with their baccalaureate degree and did not have the sense of career ladder and academic improvement. This result is congruent with the findings of Macyk [17] who reported that the majority held a bacca- 
laureate degree in nursing. Incongruently, Bina et al., [15] and Scherb, Specht \& Loes [16] stated that more than a half of participants had educational level less than a baccalaureate degree; and less than one third of them had baccalaureate degree or higher.

Also, the majority (95.7\%) of study sample was working full time. It is possible that participants who have been in nursing for many years and working full-time have more experience within the organization and the hospital work environment and therefore were more interested in participating in this study regarding decisional involvement. Congruently with the present findings, Macyk [17] noted that the majority of participants were working full time and it was significantly correlated with their involvement in decision making.

In terms of means and mean percentages of study sample decision making abilities, the study findings represented that ranking of highest mean percentages were given to reasoning, experience, recognition, critical thinking and self-awareness abilities $(91.61 \%, 89.13 \%, 87.75 \%, 85.60 \%$ and $83.33 \%$ respectively). While, the lowest mean percentages were given to intuition and reflection abilities (65.41\% and $69.37 \%$ respectively).

This result is congruent with the findings of Bittencourt and Crossetti [18] who reported that critical thinking, experience and reasoning had high rankings in their study, while evidence based and reflection had lower rankings. Furthermore, Ghazivakili, Nia, Panahi, Karimi, Gholsorkhi, and Ahmadi [19] reported that the highest mean score was belonged to reasoning skill. In contrast with the present findings, Salehi et al., [20] and Noohi, Karimi-Noghondar \& Haghdoost [21] found a low mean score of critical thinking skills among nurses. Also, Fero et al., [22] reported that nurses had deficiencies in critical thinking and recognition abilities. Moreover, Grosser [23] concluded that the lowest mean percentage was given to reasoning.

Regarding to mean and mean percentage of study samples' decision making involvement, the results of the present study showed that the highest mean percentage (49.61\%) was given to controlling, while the lowest mean percentage $(40 \%)$ was given to information access dimension. This result was incongruent with the results of Brunoro [24] who reported that the highest mean score was given to negotiation and conflict resolution while the lowest score was given to control.

The current findings shows that there is no statistical significant correlation between study sample's decision making abilities and their decision making involvement $(p=0.38)$. It may be a result that the top management depends on the organizational hierarchy regardless the employees' abilities. In contrast to these results, Felstead, Gallie, Green $\&$ Zhou [25] reported that there was positive relation between the respondents' skills and their involvement in decision-making. Furthermore, Muindi [26] and Zubair, Bashir, Abrar, Baig and Hassan [27]reported that employee's abilities were positively related with their participation in decision making.

\section{Conclusion:}

The study concluded that decisional involvement is performed according to the management positions regardless the staff abilities to make a decision.

\section{Recommendations:}

Based on the findings of this study, the following recommendations are suggested:

1- The current organization should provide training courses to improve decision making abilities of nursing staff.

2- Nursing director should increase baccalaureate nurses' involvement in decision making process.

3- Nursing director should put an evaluative measure to be used as a standard in choosing managerial and administrative position regarding their abilities and skills regardless their ages.

\section{References}

1- DORGHAM S. and AL-MAHMOUD S.: Leadership Styles and Clinical Decision Making Autonomy among Critical Care Nurses: A Comparative Study IOSR Journal of Nursing and Health Science (IOSR-JNHS) e-ISSN: 23201959. p-ISSN: 2320-1940 Volume 1, Issue 4 (May-Jun. 2013), pp. 71-83. Retrieved from, 2013.

2- EFFKEN J.A., VERRAN J.A., LOGUE M.D. and HSU Y.: Nurse managers decisions: Fast and favoring remediation. Journal of Nursing Administration, 40 (4): 188-95. Doi: 10.1097/NNA.0b013e3181d40f7c, 2010.

3- FRANK P.: Critical Thinking and Decision-Making Skills In D.L. Huber (Ed.), Leadership \& nursing care management (65-82). St. Louis, Missouri: Saunders, 2014.

4- BASAVANTHAPPA B.T.: Management of nursing services \& education (1 st ed.). New Delhi, India: Jaypee, 2011.

5- ANDERSON F.: A Case for Measuring Governance. Nursing administration quarterly. 35. 197-203. 10.1097/ NAQ.0b013e3181ff3f42. retrieved from https://www. researchgate.net/publication/5 1202583_A_Case_for _Measuring_Governance, 2011. 
6- HOYING: Decentralization and Shared Governance. In D.L. Huber (ED.), Leadership \& nursing care management (246-255). St. Louis, Missouri: Saunders, 2014.

7- MAHMOUD H.G.: The Relationship between Nurses' Professional Shared Governance and Their Work Empowerment at Mansoura University and Specialized Medical Hospitals. Journal of Biology, Agriculture and Healthcare, 6 (18). pp 2224-3208. Retrieved from https://iiste.org/ Journals/index.php/JBAH/article/viewFile/33023/33 919, 2016.

8- GILLESPIE M. and BARBARA L.P.: Helping novice nurses make effective clinical decisions: The Situated Clinical Decision-Making Framework. Nursing education perspectives. 30. 164-70. Retrieved from https://www. . researchgate.net/publication/26674998 Helping novice nurses_make_effective_clinical_decisions_The_Situated_Clinical_Decision-Making_Framework, 2009.

9- CHEN S., HSU H., CHANG C. and LIN E.: An exploration of the correlates of nurse practitioners' clinical decisionmaking abilities. Journal of Clinical Nursing, 25, 10161024, doi: 10.1111/jocn.13136. Retrieved from https://. onlinelibrary.wiley.com/doi/pdf/10.1111/jocn.13136, 2016.

10- HAVENS D.S. and VASEY J.: (December). The staff nurse decisional involvement scale, Report of psychometric assessment. Nursing research, 54 (6): 376-83. Retrieved March, 8, 2016 from http://decisionalinvolvementscale. web.unc.edu/files/2010/04/DIS-Havens-Vasey-nursingresesarch-paper.pdf, 2005.

11-HESS R.G.: Slicing and dicing shared governance: In and around the numbers. Nursing Administration Quarterly, 35 (3): 235-41. http://dx.doi.org/10.1097/ NAQ.0b013e3181ff387d, 2011.

12- FRENCH D.J., WEST R.J., ELANDER J. and WILDING J.M.: Decision-making questionnaire. Ergonomics, 36 (6): 627-44. Retrieved March, 22, 2016 from www.rjwest. . co.uk/downloadfile.php?filename=uploads resources/. 1993.

13-Nurse Manager Leadership Partnership (NMLP): Retrieved from https://www.aacn.org/ /media/aacn-website/ education/online-courses/nurse-manager-inventorytool.pdf?la=en, 2008.

14-BINA, et al., BINA, J.S., SCHOMBURG M.K., TIPPETTS L.A., SCHERB C.A., SPECHT J.K. and SCHWICHTENBERG T.: Decisional Involvement: Actual and Preferred Involvement in Decision-Making Among Registered Nurses. Western Journal of Nursing Research, 36 (4): pp. 440-55. Retrieved from http://journals.sagepub.com/ doi/ 10.1177/01939459135037 17\#articleCitationDownl oadContainer, 2013.

15- SCHERB C.A., SPECHT J.K.P., LOES J.L. and REED D.: Decisional Involvement: Staff nurse and nurse manager perceptions. Western Journal of Nursing Research, 33 (2): 161-79. http://dx.doi.org/10.1177/0193945910378853, 2011.

16-AHMED M.Z. and SAFADI E.G.: Decisional involvement among Nurses: Governmental versus private hospitals in Jordan. Health Science Journal, 7, 18-27. Retrieved March, 18, 2016 from http://www.hsj.gr/medicine/decisionalinvolvement-among-nurses-governmental-versus-privatehospitals.pdf, 2013.
17- MACYK I.: Staff Nurse Engagement, Decisional Involvement, Staff Nurse Participation in Shared Governance Councils and the Relationship to Evidence Based Practice Belief and Implementation. PhD dissertation. Retrieved from https://pqdtopen.proquest.com/doc/1905782547 html? FMT=AI, 2017.

18- BITTENCOURT G.K.G.D. and CROSSETTI M.G.O.: Critical Thinking Skills in the Nursing Diagnosis Process. Revista Escola de Enfermagem da USP, 47: 341-7, Retrieved from http://www.scielo.br/pdf/reeusp/v47n2/ en_10.pdf, 2013.

19- GHAZIVAKILI, NIA, PANAHI, KARIMI, GHOLSORKHI and AHMADI, 2014.

20- SALEHI M., BÉDARD Y. and RIVEST S.: Aformal Conceptual Model and Definitional Framework for Spatial Datacubes. Geomatica. 64 (3): pp. 321-32. Retrieved from http://yvanbedard.scg.ulaval.ca/wp-content/documents/ publications/588.pdf, 2010.

21- NOOHI E., KARIMI-NOGHONDAR M. and HAGHDOOST A.: Survey of critical thinking and clinical decision making in nursing student of Kerman University. Iranian journal of nursing and midwifery research. Retrieved from https://www.semanticscholar.org/paper/ Survey-of-critical-thinking-and-clinical-decision-NoohiKarimi-Noghondar/ab5c7cf0098433e4dd5cf70a2b6c22ae8be901bf, 2012.

22- FERO L.J., WITSBERGER C.M., WESMILLER S.W., ZULLO T. and HOFFMAN L.A.: Critical thinking ability of new graduate and experienced nurses. Journal of advanced nursing. 65. 139-48. 10.1111/j.1365-2648.2008. 04834.x, 2008.

23- GROSSER M. and KLOPPERS M.: The Critical Thinking Dispositions of Prospective Mathematics Teachers at a South African University: New Directions for Teacher Training. International Journal of Educational Sciences, 7 (3): 413-27, 2013.

24- BRUNORO C.S.: Clinical Nurse Perceptions of Who Governs the Professional Environment Including Control over Practice in Provincial Hospitals in Saskatchewan. Master thesis. P.p i-214, 2007.

25- FELSTEAD A., GALLIE D., GREEN F. and ZHOU Y.: Employee involvement, the quality of training and the learning environment: An individual level analysis. The International Journal of Human Resource Management. 21 (10): 1667-88. Retrieved from _ https://www. researchgate. net/publication/2543 00580_Employee_involveme nt_the_quality_of_training_and_the_learning_environ ment_An_individual_level_analysis, 2010.

26- MUINDI F.K.: The Relationship between Participation in Decision Making and Job Satisfaction among Academic Staff in the School of Business, University of Nairobi. Journal of Human Resources Management Research, 16 (11), 98-123, 2011.

27- ZUBAIR A., BASHIR M., ABRAR M., BAIG S.A. and HASSAN S.Y.: Employee's Participation in Decision Making and Manager's Encouragement of Creativity: The Mediating Role of Climate for Creativity and Change. Scientific Research Publishing, 8 (3): PP. 306-21. Retrieved from https://www.scirp.org/journal/ PaperInformation.aspx?PaperID=56549, 2015. 


\section{العلاقة بين إشراك هيئة التمريض فى إتخاذ القراربقدراتهم على صنع القرار

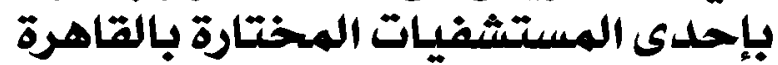

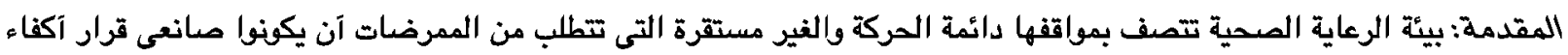

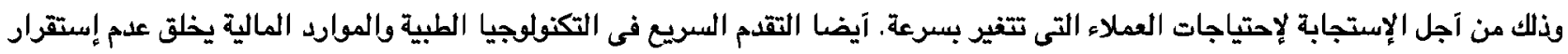

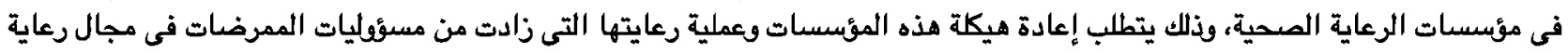

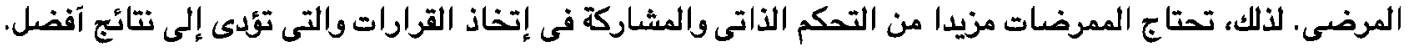

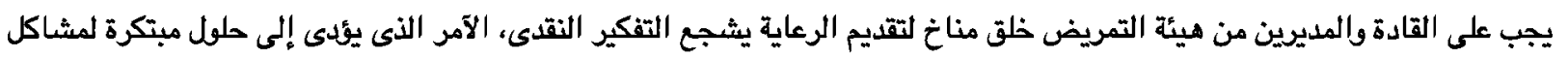

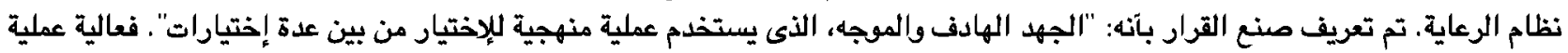

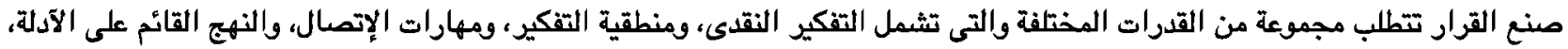

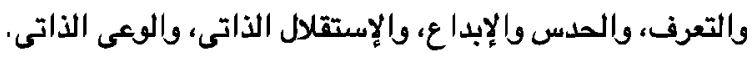

الهدف النهائى للبحث: الهدف من الدراسة هو دراسة العلاقة بين إثراك هيئة التمريض فى إتخاذ القرار بقدراتهم على صنع القرار بإحدى

المستشفيات المختارة بالقاهرة.

تصميم البحث: إستخدام منهج الإرتباط الوصفى لتحقيق هدف البحث.

عينة البحث: شملت عينة البحث 110 من الحاصلات على بكالويوس تمريض.

آداة البحث: يوجد آداتى بحث:

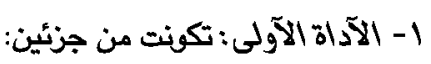

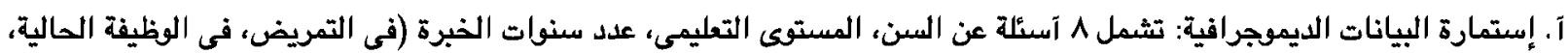

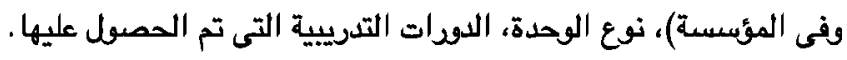

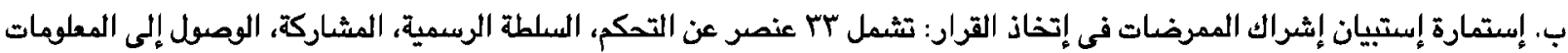

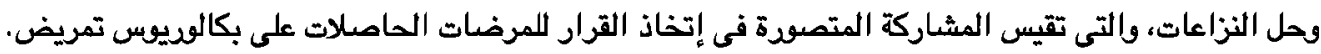

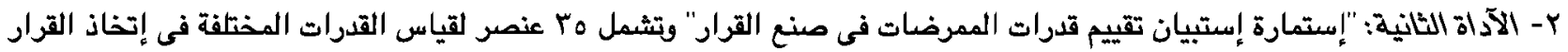

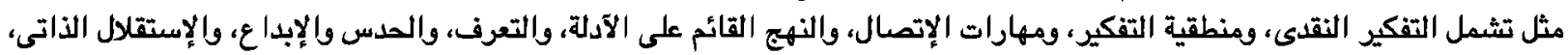
والوعى الذاتى.

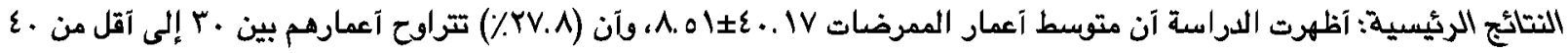

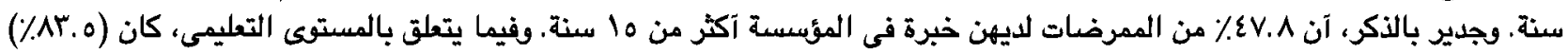

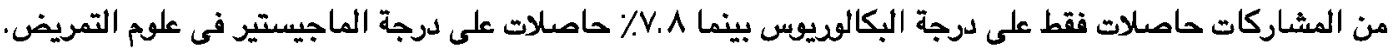

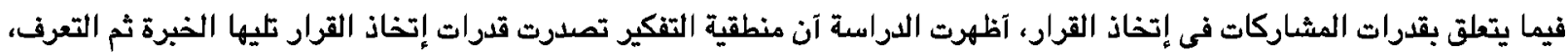

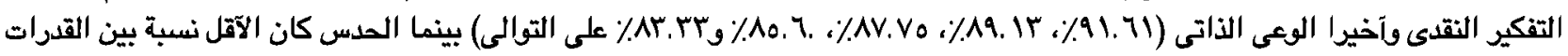

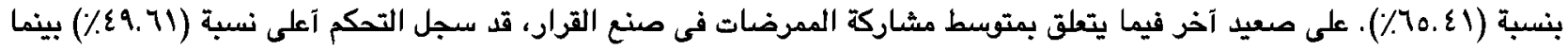
الوصل إلى المعلومات سجل آقل نسبة (.ع٪).

آظهرت الدراسة آنه لا توجد علاقة بين قدرات الممرضات فى صنع القرار وإشراكهم فى إتخاذ القرار (0.38) ).

التوصبات : بناءا على نتائج هذه الدراسة، تم إقتراح التوصيات التالية:

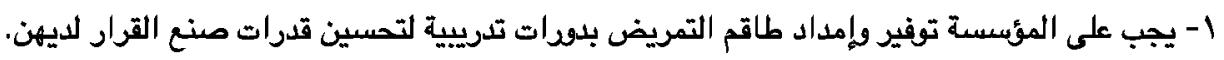
r- يجب على مديرة التمريض آن تزيد من مشاركة الممرضات فى عملية إتخاذ القرار.

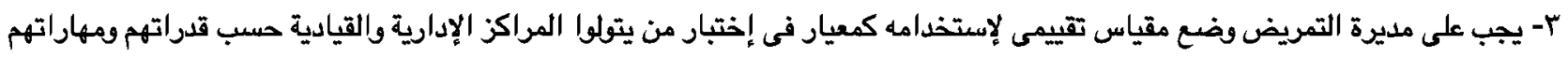
بغض النظر عن أعمارهم. 